\title{
The Impact of Online Learning on International Students' Studies Amid the Covid-19 Pandemic During the 2020 Spring Semester: A Case Study of Southwest University
}

\author{
Muganga Allan ${ }^{1 *}$, Naomy Kalabwa Leah ${ }^{2}$ Tebatso Namanyane ${ }^{3}$ and Md. Mirajur Rhaman Shaoan ${ }^{4}$ \\ ${ }^{1}$ School of Statistics and Mathematics, Southwest University \\ Beibei District, China \\ *Email: allmuganga98 [AT] gmail.com \\ ${ }^{2}$ Faculty of Education, Southwest University \\ Beibei District, China \\ Email: naomy.zulu [AT] gmail.com \\ ${ }^{3}$ Faculty of Education, Southwest University \\ Beibei District, China \\ Email: namanyanetn [AT] @hotmail.com \\ ${ }^{4}$ Faculty of Education, Southwest University \\ Beibei District, China \\ Email: saonmiraj [AT] email.swu.edu.cn
}

\begin{abstract}
Toward the end of 2019 and since the beginning of 2020, there has been a worldwide collapse of the pandemic disease called covid-19 that caused a complete shutdown in several countries. As a result, schools, universities and other institutions of higher learning were forced to close. The only way learning could take place was through online learning. Unplanned online learning brought uncertainty among institutions, educators and learners which needs to be examined. The purpose of this case study was therefore to explore how online learning during the COVID-19 period influenced SWU international students' studies, and to understand the attitude of these international students toward online learning during the covid-19 period and finally finding out strategies that $S W U$ international students used to tackle the challenges they encountered through online learning. Semi-structured interviews were conducted among twelve international students offering different online courses. Researchers used content analysis to help them arrive at findings and conclusions. Results from the research showed that poor network connectivity, limited class participations were among the strongest themes to address the first research question. Passion for learning and apathy of online learning were among the themes under students' attitude. Strategies used to cope up with the challenges faced included prior class preparations and seeking better internet connectivity showed up.
\end{abstract}

Keywords---- Covid-19, Online Learning, Student Attitude, Strategies

\section{INTRODUCTION}

COVID-19, the infection caused by a novel coronavirus detected in Wuhan (province of Hubei) in December 2019, is now a pandemic declared by the World Health Organization, raising concerns about widespread fear and the anxiety among individuals (WHO, 2020a, b). This epidemic has seen many whole towns in China effectively put under mass lockdown since the end of January 2020. Brooks et al. (2019) evaluated and reported that confinement could produce "posttraumatic symptoms of stress, anger, and confusion. Stress factors included a more extended duration of isolation, fears of infection, dissatisfaction, boredom, insufficient supplies, inadequate knowledge, financial loss, and stigma. Some researchers have suggested prolonged effects (Brooks et al., 2019). Besides, previous research has shown that in recent years, contagious diseases of unpredictability such as SARS, Ebola, the H1N1 influenza contagion of 2009 and 2010, Middle East respiratory and equine influenza syndromes have also had adverse psychological implications (Bai et al., 2004; Taylor et al., 2008; Wu et al., 2009; Liu et al., 2012; Sprang \& Silman, 2013; Rith-Najarian et al., 2019).

The COVID-19 pandemic is a health issue in the first place. Many countries have agreed (rightly) to shut down schools, colleges, and universities. As Massive Open-Online Courses have been developed rapidly, over 500 online Chinese 
universities' courses, have involved almost 3 million people (Shang \& Cao, 2017). The crisis crystallizes the policymakers' dilemma between closing schools (reducing interaction and saving lives) and keeping them open (allowing teachers to work and maintaining the economy). Most families around the world experience the extreme short-term disruption: home-schooling is not only a massive shock to the income of the parents but also the social life and learning of the children. Teaching moves online, on an untested and unparalleled scale. Student evaluations also move online, with a lot of trial and error and uncertainty for all. Many appraisals were canceled. Notably, such interruptions may not only be a short-term problem but will also have long-term consequences for the populations affected and are likely to create inequality.

For skills growth, going to school is the best public policy tool available. Viewing it from an economic perspective, the primary goal of the university is that it increases the students' ability. However, school time can be fun and can improve social skills and social consciousness. This also takes only a short time at school, and a relatively short period of missed school would also have implications for ability development. But may we investigate how online learning has influenced Southwest university studies by way of COVID-19? Not specifically because we're in a new environment, but other studies can get a scale.

The Chinese government has ordered a nationwide school closure in response to the COVID-19 outbreak as an emergency measure to prevent the coronavirus infection. China's Ministry of Education and China's Ministry of Industry and Information Technology (2020) proposed 'suspending classes without suspending learning;' As a result, many international students around china used different learning methods, including online learning based on various platforms, to achieve the target from mid-February 2020. Schools can actively promote good personal hygiene, a healthconscious schedule, encourage physical activity, a healthy diet, good sleeping habits, and incorporate these health promotion resources into the curriculum (Brazendale et al., 2017). Life and learning at the university campus have a crucial role in students' mental development, and psychological impact on university students has been hypothesized in the home containment-related issues. How would school closures and online learning affect international students at SWU University, though?

International students are being focused on because of their usefulness to the economy of China. International students' economic impact cannot be overstated, nor can it be limited to only tuition, food and clothing, transport, and other living allowances. International students' accompanying advantages go beyond the economy. Education for students from other countries is also another way china can win over hearts and minds, and the opportunity to improve and reform the country's education system. This, therefore, brings out the specialness of international students in this study. Learning must be continuous for them, and in this case, it's online learning due to the COVID-19 pandemic.

\subsection{Statement of the Problem}

The global shutdown of educational institutions has led to substantial disruptions in student learning, delays in internal assessment, and the cancelling or replacement of public performance assessments for an inferior alternative (Burgess \& Sievertsel, 2020). Burgess \& Sievertsel (2020) further notes that home-schooling is not only a massive blow to the prosperity of the parents but also the social life and learning of the children. Teaching and learning have generally been moved to online untested during this period and caused many problems for learners. Student reviews are also moving online, with teachers and students getting many trials and errors and confusion.

Therefore, education systems are heavily affected by the measures taken against the spread of the COVID-19 virus, such as temporarily shutting down institutions. However, some institutions in Asian countries such as China have resorted to short-term unplanned online learning and teaching. Online learning is now a popular learning tool. Besides, several higher education institutions have used online learning in their teaching to address different learning needs (Artino\& Stephens, 2009). According to (TUAC 2020) students' emotional well-being and health are priorities because distant learning demands suitable hardware and a high-speed internet connection. Therefore, this study aimed to explore how online learning as a result of COVID-19 has affected international students' studies of Southwest university during the Covid-19 period in the spring semester of 2020.

\subsection{Main Objective}

This case study aimed to understand the impact of online learning on international students' studies of SWU during the COVID19 period of the 2020 spring semester. The study further sought to examine the students' attitudes towards online learning and their strategies to cope with the challenges faced.

1. The study's main objective was to investigate the impact of online learning on international students' studies of SWU due to COVID 19.

\subsection{Specific objectives}

2. To explore SWU international students' attitudes towards online learning during the COVID 19 period.

3. To find out strategies used by SWU international students to cope with the challenges faced during online learning. 


\subsection{Research Questions}

1. How has online learning during the COVID-19 period affected southwest university international students' studies for the spring semester of 2020 ?

2. What are the attitudes of SWU international students towards online learning during the COVID-19 period?

3. How have international students of SWU managed to cope with the challenges faced during online learning throughout the COVID-19 period?

Findings of this study will help the international students of SWU, teachers, and the international college at large. Coming up with the challenges international students face will pave the way for proper solutions on how most of the challenges can be dealt with and eventually solved.

At the same time, this study encourages china's government as the primary stakeholder to decide how the affected international students can be helped and possibly finding measures and strategies of keeping them safe.

\subsection{Theoretical framework}

\section{REVIEW OF LITERATURES}

A theoretical framework may also be called a paradigm, and a paradigm for studies leads to the analysis, examination, and interpretation of the subject matter (Glesne, 2011). This current study is constructivist and interpretative.

'Wilhelm Dilthey developed the interpretive and constructivist approach and other German philosophers, known as Hermeneutics, out of the theory of phenomenology by Edmund Husserl' (Mertens, 2005, p.12 citing Eichenlberg, 1989). The constructivist interpretative approach focuses on the sample analyzed to collect data and considers the participants' perspectives and experiences. In this way, the researcher creates data meaning trends and typically uses tools and interpretation for qualitative data collection (Mackenzie \& Knipe, 2006). For the current research, it was appropriate to take a constructivist-interpretative approach to analyzing patterns of interpretation to see how students interpret the effects of online learning and their attitudes toward online learning. A constructive interpretative approach was chosen primarily because it offered researchers an in-depth understanding of the effects and attitudes of online learning and reporting on their results. This involved studying and interpreting the significance of the participants' attitudes and expectations through their perspective (Koskinen, Zimmerman, Binder, Redstrom \& Wensveen, 2011).

The study reflects the participants' views and perspectives in interpretative research and identifies the researchers' subjectivity. We described the analysis with detailed statements of opinions and opinions from the participants in this study (Gubrium, Holstein, Marvasti, \& McKinney, 2012).

\subsection{Online learning}

With the immediate sending and shutting down of university students from all the campuses in China and elsewhere worldwide, many courses have been delivered virtually. There have, however, been some noticeable teething issues. According to observers, there are some possibilities for the future to be present (Bao, 2020; Donitsa-Schmidt \& Topaz, 2018; Filius et al., 2019). The use of technology in education has advanced in two decades. In several schools that have adopted digital learning (Murphy, 2020), there has been an increase in complexity and quality. UNESCO estimates that COVID-19 has drawn over 1.5 billion students in 165 countries. This indicates $87 \%$ of the student population worldwide.

Online learning has become popular channels for learning as an alternative to face-to-face learning in recent years. The Internet is also an online teaching distribution tool. So far, online learning has been a significant focus on offering alternatives to conventional face-to-face education experiences (Douglas \& Van Der Vyver, 2004). Online learning provides students with comprehensive learning experiences in diverse cultures (Keengwe \& Kidd, 2010). (Pituch \& Lee, 2006) argue that online learning provides teaching support for students in a certain way. Online learning incorporates many different technologies, including computer learning, web-based education, immersive training, and digital collaborations. Online learning also enables students to participate, irrespective of place, and time (Richardson \& Swan, 2003). However, other students may have trouble because of low internet access, depending on their population position. Online learning and e-learning can be interchangeably used. Govindasamy (2002) points out that e-learning requires guidance through all electronic means on the Internet, the intranets, extranets, and hypertext/hypermedia documents. Although some dispute exists about acceptable e-learning or electronic learning, it is widely agreed that learning material can be delivered via the Internet, personal computer, personal digital assistant, or CD-ROM in various formats such as text and video and files. (Sandars \& Langlois, 2005).

As (Liaw, Huan \& Chen, 2007) have noted, however, online learning has some advantages. Firstly, it is cost-friendly. Second, the materials used thereof are timely and accurate. Thirdly, it is an approach to learning just in time. Fourthly, it builds universal cultures. And eventually, it offers a value-added learner program (Rosenberg, 2001). Govindasamy (2002) claimed that e-learning is a way of solving authentic success and learning. However, due to the ongoing pandemic, research has also shown that international students are affected either positively or negatively in one way or the other. 
All students in the Chinese mainland were required to stay at home and continue to learn online from kindergarten through the doctorate. This came to an end in January following the New Year Lunar break. 30 million tertiary students in some 3000 institutions were affected by the pandemic. Many of these institutions have taken advantage of precipitated online classes (Bao,2020; UNESCO,2020) to try to fill the gap in areas which are adversely affected by the eventual academic term. it's not only the Chinese students but also students from other countries were affected by the pandemic. Nearly half a million international students had to leave their home countries to continue learning and gain access to the required learning materials (Bao, 2020). Meanwhile, the travel restriction on returning to the campus is also exploring alternatives in other countries around the world for millions of students. Higher education institutions have had to stop studying and close their campuses in other adverse regions such as Italy, Iran, and Singapore and have moved into online learning rather than face to face interaction (UNESCO 2020).

Wan (2020) notes that COVID-19 has shown students a significant difference in the digital divide. A student needs to have access to the website to effectively learn online via different platforms. In terms of connectivity, learning from the online platform would be the requirement for learning from devices such as a computer, laptop, tablet, or smartphone and the internet. There are concerns in urban areas that some students need to share computers, and because of poor internet access or lack of technology, they do not completely use the lessons online. However, internet coverage is poor in rural and remote areas where most of the international students are situated. Some villages don't even have access to electricity, or night-time usage is very small.

Cheng (2020) says that while making their decisions to close their physical campuses and transfer to online classes, colleges and universities have also neglected to acknowledge that many international students do not have a home outside of those universities. While some institutions give exceptions for special needs students, they frequently ignore international students when designing these policies. That's particularly worrying given that studies have shown that when it comes to reaching out for support, international students may be culturally impaired. When a problem occurs, not many international students are prepared to speak for themselves.

Many of the international students have been affected due to the ongoing online learning because of COVID 19, for instance, the graduate students back in their home countries. In the final part of a research project, they have encountered major teaching disruptions, they are experiencing major disruptions in their tests, and eventually, they are likely to graduate at the start of a significant worldwide downturn. Evidence indicates that weak employment conditions at the entrance into the labour market lead people to accept lower-paid jobs, and this has lasting effects on certain professions. (Oreopoulos et al., 2012) show that students graduating from programs with high expected income can accommodate for their poor starting point through both domestic and cross-company earnings, but graduate students from other programs have been found to encounter permanent losses in earnings from graduating in a recession.

The switch to the online distribution style inspired many teachers and students worldwide. The faculties already began writing lesson plans to offer to teach to their students online. Online education is not a modern method of teaching for many universities. Many faculty members receive training to use online instructional platforms as the only means of distribution or as an extension (Cheng 2020). Nonetheless, there is always a risk that any shift that isn't familiar with this kind of teaching won't be able to cope with the style (Cheng, 2020). In this crucial situation, many international students are studying in many universities around china and specifically those in SWU for whom it was not possible to return to their country back to school for studies. Therefore, the only option left was switching to online learning.

The surroundings of Internet learning have changed the way people learn. Learning, discussions, exchange of information usually found in face-to-face learning is viewed differently in online learning. (Yang \& Lin, 2010) suggested that when they use it, students can interpret the Internet differently. Therefore, this increases a student's attitude making use of online learning.

It is nevertheless a fact that COVID-19 has greatly impacted the educational institutions and the structure of educational institutions. According to the statement made by the UNESCO Secretary-general Audrey Azulay (2020), we have never witnessed the disruption of educational institutions on this large scale. This would help us to get an idea about how big this destruction is the impact that his malfunction can create. The entire global academic calendar has been disturbed and the student is directly affected by this. In the present situation, the schools and colleges have immediately closed and turned into the online academic system with which most of us are not familiar. According to the observations made by different educational experts, they think that the future is going to be like the present and we need to be prepared for this. They believe that our coming generations and the young children might not be able to see the traditional methods of schooling which normally occurs in educational institutions. In the past few decades, humans have made a lot of technological advancements in this sector, but the challenge has stilled arise that they need to formulate an extensive system under new conditions (Demuyakor, 2020).

The recent studies conducted by UNESCO have claimed that about 1.5 billion students out in 145 different countries have been affected by the pandemic and this accounts for a total of $87 \%$ of the student population. Another survey conducted by the 'Times Higher Education' among 200 different respondents in 45 different countries of the 6 continents and the majority of them is convinced of the fact that the online education system is not equivalent to what they get while physically attending the school or college. On the other hand, $63 \%$ of the educational institutions in 2030 would be offering their courses online mode. Whether the students have accepted this new model of education or not, but the educational institutions in their new policies are focused on converting their mode of education to an online system. 
Many of the experts also believe in the fact that online institutions are equally effective as compared to the face-to-face mode of education. The researchers have also presented a study in which they have shown that the students who are attending the online courses have outperformed the classroom-based students in many of the courses. The demographic advantage is also another benefit that forces people to support the online education system (Zuochen Zhang, 2010).

If we analyze the e-learning systems, researchers claim that this is not only needed for the present times of the pandemic, but they also think that it is the demand of the modern world. Comparing the advantages of e-learning with that of the conventional system, the online method of learning is more suitable in a way that the learner can complete their educational process at the convenience of their places and to some extent at their own preferable time. they simply just need to have the subscription to the course and by just logging in to their devices, they have the access to the entire content. The lecturers are available to you at your places where you can more comfortably communicate with them. This online method is normally being used by most of the students in any of their educational cycles and this has more potential to provide you with the content and resources which you cannot get from the classrooms. But there are some of the challenges that are also related to this as our students, as well as the teachers, are not fully skilled by using this mode of education which further creates many other issues both of the student and the instructor's end (Lynn Fish, 2014).

The instructional strategies have been remolded for the implementation of the e-learning system in different educational institutions. Various contingency plans have been introduced to overcome the technical issues that come under this system. For example, to facilitate students and to provide ease in understanding this system, their normal course modules have been divided into different small portions so that they can easily manage their work plan. Similar strategies have also been made for the instructors to facilitate the students. There are also separate tutorials that are organized for just the teachers to let them familiarize with this system. This is due to the problem that in many countries especially in underdeveloped counties, the teachers are not fully capable to operate this online system of learning. There are some of the shortcomings that exist in the familiarity of the instructors towards the latest technology. The examination policies are also affected by this as it must be made according to this new education system. Students are required to get familiar with the new grading policies and methods which is also another challenge for the students to easily understand this as a lot of them face serious issues related to this (Dong, 2020).

The students are not alone in this situation as instructors are also experiencing great mental burden. The entire load is enforced by the administration on the instructor and they must follow them in every situation. There are many challenges that teachers face during teaching online as some of them are technical issues that are not addressed. The lack of resources in some of the countries is also causing the discontinuation of the teaching system. Apart from that, there are some of the skilled-based problems that lecturers are also facing. Many of the teachers that are teaching their students for more than a decade and now must move to a new system which is unique for them. Adjusting to this is not only difficult for the students but the teachers are also facing the same problem. There are different technological barriers which are further contributing towards increasing these kinds of issues and the problem is that these cannot be resolved in a single day as it requires a sufficient amount of time to overcome all these issues and till then, they have to incorporate these issue in their teaching systems (Novikov, 2020).

\subsection{Students' Attitude towards online learning}

Sun, Tsai, Finger, Chen \&Yeh (2008) describe the attitude of the students towards online learning as student's impression of involvement in online learning activities through computer use. To understand how online learning has affected international students' studies throughout the COVID 19 period, this study believes that the attitude of students plays a significant role. It is so because the online learning environment forces students to have their learning arrangements, of which some might have difficulties in various ways.

Students must take a more active role in their learning as the online learning setting is not a teacher-centered environment. Students participate in online learning, track learning time, and procedures on their own (Liaw, Huang \& Chen, 2007). However, (Ho \& Kuo, 2010) argue that the computer attitudes of students play an important part in the usability of online learning. Previous studies have shown that attitude and self-efficacy have been described as important factors influencing the encouragement, engagement, and success of learners in learning environments based on the Internet (Peng, Tsai \& Wu, 2006). Sun et al. (2008) cited Piccoli et al. (2001) finding that students would become more comfortable and successful in online learning if they are not afraid of uncertainty in information technology (positive attitude). Their research also suggests that attitude affects curiosity in learning (Hannafin \& Cole, 1983).

Student attitude toward learning online often depends on the characteristic of the program. Through their empirical research, (Pituch \& Lee, 2006) suggest that if the program is user friendly, the student's purpose of using the program is more significant. Their research also indicates the program that enables the students to communicate efficiently and provide access to the contents of the course at the time encourages the student to use the program to learn. As stated by Selim (2007), the attitude of students to participate in online learning is also linked to the previous computer usage experience of students. Furthermore, the student's attitude towards the Internet is also critical for determining the encouragement, engagement, and success of learners in the online learning environment (yang \& Lin, 2010).

Students' resistance to online learning is focused on the perceptions of the students that online courses tend to be challenging, overwhelming, and demanding (Halstead \& Coudret, 2000; Zsohar \& Smith, 2008). Additionally, students 
do not seem to expect the increasing demand for online courses and are conditioned on passive training (online environments typically require highly active students), believing that learning content is presented in a lecture format (Freeman et al., 2006; Kozlowski, 2004).

Petrides (2002) performed a qualitative analysis of web-based learning to assess the experiences of the learners. The research took place in a mixed online school at the university, meaning that the course was a one-semester regularly scheduled class with web-based technology as an addition. Some interviewees said that they preferred to think deeply about the topics in addition to providing verbal answers when answering in writing. They demonstrated that they would regularly focus on one another's thoughts because of the public and the permanent appearance of the discussion posts on the Site. "There is something that causes you to focus closely on subjects when you have to respond in writing" (Petrides, 2002, p.72). Another participant reiterated that view and indicated that online technology allowed more reflection in classrooms than in a face-to-face chat.

According to Henderson (2017), culture has a very strong role in the design, management, and communication of the learning systems. Due to this many undergraduate students are provided with the opportunity to go to different countries and this would give them a chance to experience a diverse set of environments. The experts believe that the learning systems greatly enhance when students study with fellow friends that are from different cultural backgrounds. Sitting in the classrooms and allowing them to share their perspective have a very positive impact on the thinking capabilities of these students. Now with the online learning systems, these conditions have slightly changed, and people are still arguing about this. Many of them believe that this transition will allow more students from different geographical regions to enroll in the courses and they would not have many geographical limits were attending a course. While some argue that the entire purpose of exchanging students and allowing them to study in different cultures is only met when there is a classroom-based education system (Muhammad Adnan, 2020).

Recent studies have shown a great transition in the education system towards the online learning system. The authoritative personalities believe that the educational outcomes that are gained from online learning mode are the same as that of the ones that are obtained from the face-to-face learning mode. Many still argue that many intrinsic differences exist in the online teaching methods and this method cannot replicate the learning system that is done in the traditional classrooms. We also need to understand the perspectives of the students especially of the international students that are greatly suffered by this change in the system. Different factors also contribute towards their decision-making step with the change in the education level. With the pandemic to halt every activity in the whole world, international students are not sure about the future of their studies. They are not sure the future that whether there coming semesters would be completed in the online learning mode of the situation may get changed. This confusion further continues that the objective that these students particularly have are also at stake and as the situation is also uncertain, so students are afraid that they may not lose their academic year due to this (Soni, 2020).

\section{METHODOLOGY}

This was a qualitative case study design since it enabled the researchers to investigate the way online learning as an impact due to COVID 19 affects foreign students of SWU. The method was chosen since a case study seeks to clarify why a decision was taken, the process of implementation, and the outcomes (Yin, 2009). A case study helps describe a mechanism by the participants' perspectives and experiences in real-life circumstances (Gall et al., 2007). It also ensures that the subject is not explored through a single lens, but rather a variety of lenses that allow for the revealing and understanding of different aspects of the phenomenon (Baxter \& Jack 2008). Pandey \& Pandey (2015) describe research design as the framework or strategy for a study used as a guide for data collection and analysis. It is a plan which is followed when a study is being conducted. For the analysis of research, methodology researcher is using content analysis method for semi-structured interviews. This technique starts from the material, data collection, characteristics of data collected, the codification of data, and applicability of data reliability and interpretation of findings. Pandey and Pandey (2015) define the significance of the population as the total number or group of people with similar traits from which a sample should be created. The population of this inquiry was all international students in China, while international students in southwest university were the target population of which the sample was drawn.

Convenient sampling was applied to the 12 students that participated in this study. Ten students where physically approached and interviewed while the other two students outside china, were reached via phone calls. The principle of data saturation in studies is beneficial; however, when data saturation has been reached, it does not include any realistic guidance (Guest et al. 2006). Guest et al. (2006) further noted that data saturation might be achieved by as little as six interviews, depending on the population's sample size. Therefore, for this study to reach saturation, 12 interviewees participated.

\subsection{Material}

The material for this research presented practical exposure of student life in this COVID-19 for online learning; either it has positive outcomes for students or negative. Information collected with semi-structured interviews questioning from those students who came here from outside china for studies. The tool for the material of this study was semi-structured 
Interview questions. Twelve students (12) participated in the interview carried out by the researchers. Ten of these students were within Southwest university, and two were outside China. For the participants abroad, phones call recordings were made. An interview is one of the methods by which study results can reach saturation through probing.

\subsection{Data Collection}

Collection of data is the process of measuring and gathering information in a system that helps you to answer relevant research questions and evaluate the results of a targeted variable. This study used interviews in semi-structural form. Semi-structured interviews are primarily used in qualitative studies and occur when researchers use open-ended questions and address one or more participants in general (Creswell 2012). For this study, researchers gave the details of the study and informed the participants that the interviews would be recorded. If they agreed, they would also be assured that their names and personal information would be kept synonymous. Only two interviewees were called via phone calls and interviewed since they were outside China. For the participants within SWU, researchers physically approached them and were interviewed. Interviews are useful for uncovering the story behind the participant's experiences and for in-depth information. Open and semi-structured interviews allow the new ideas to emerge during the interview hence why they were suitable for the study. Data for the analysis was collected physically from ten respondents and two respondents it was collected on the call.

\subsection{Participants}

The sample of this research study were twelve international students of Southwest University, all attending online classes during the COVID 19 period of the spring semester 2020. Since we were four researchers carrying out this study, each researcher interviewed three participants, totaling to twelve altogether. Two of the participants were outside China, and the other ten were within the southwest university.

\subsection{Procedure}

The selection of study participants was the first step in the process. Convenient sampling was carried out because the participants were known by the researchers. The interviews with the participants were held shortly after the end of the spring half of 2020. During the entire interview process, conversations were recorded. Interviews were conducted in different locations to meet the needs and comfort of participants. The data were organized and mainly analyzed after the interviews were completed.

Research questions: The basic research questions for semi-structured interviews were as per research dimensions;

1. How has online learning during the COVID-19 period affected southwest university international students' studies for the spring semester of 2020 ?

2. What are the attitudes of SWU international students towards online learning during the COVID-19 period?

3. How have international students of SWU managed to cope up with the challenges faced during online learning throughout the COVID-19 period?

This research was organized into three categories as per researchers' understandings, the first category presents the effects of online learning. It presents the effects of online learning during COVID-19 students understanding, and more significantly how online learning affects students study approach, their knowledge, interaction among teachers and other classmates. All kind of physical activities during studies are affected by it. It has both positive and negatives aspects of student personal behavior to practical learning experience and opportunities. The second category is about student attitude towards online learning, how it affects students' behavior towards their studies, either student is satisfied or not? Is online learning influence student behavior, student convenience for online learning according to their residence, available internet connections and time flexibility. The third category of coping strategies is a kind of way to express the relationship between effects and attitude.

\subsection{Characteristics of data collected}

At the beginning of the study and the data collection stage, semi-structured interviews were conducted for each participant. An interview lasted about 40 minutes for each participant. Interviews took place at the convenience of the participants, such as dormitories and outside schools, at the will and convenience of participants to meet the researchers. The interview questions were subdivided into three sections in line with the research questions, i.e., a) Effects of online learning, b) student attitude towards online learning, and c) coping up with the challenges faced during online learning. These subsections further considered as code for analysis and gathered information about respondent experience vary in this dimension. Numbers of respondents were twelve; because of COVID-19, it was not easy to approach respondent but still with their corporation researchers successfully collected data as per research design. 


\subsection{Data Analysis}

Content Analysis is a tool used to evaluate the existence in any qualitative data of certain words, themes, or concepts. Using content analysis, researchers quantified and analyzed the meanings and relationships of words, themes, and concepts. The steps we followed: collected data, transcribed the data, started coding, compiled codes, arranged codes alphabetically, consolidated codes, sorted codes, labelled clusters to form categories, and then finally united categories to form themes. The qualitative content analysis goes far beyond counting sentences or extracting objective contents from texts to explore meanings, themes, and trends, which may be characteristic or latent in a text. This allows researchers to subjectively or objectively consider social reality (Zhang \&Wildemuth, 2004). This study employed the inductive content analysis approach. This study's purpose was to investigate how online learning as an impact due to COVID 19 has affected international students of Southwest University and to explore the students' attitudes towards online learning.

Interview recordings were manually transcribed by the researchers. As we completed both face-to-face and on-call transcriptions, we reflected on the purpose of the study, the literature review, and the possible issues that arose from the results. Marshall and Rossman (2006) claim that when researchers combine transcribed and original data analyses with transcribed interview data, it makes data analysis more effective and reflective. Transcripts that had been accepted were submitted to and stored as a word document. The analysis was conducted manually and followed multiple stages as one group using the description-focused coding techniques (Adu, 2019): The first step was to get acquainted with the data by converting audio data to textual data. The transcripts were read again and again, and the initial questions were noted clearly. The data were coded during the second stage, and verbal expressions were defined for each code. In the next step, all codes were compiled and alphabetically ordered. The next step involved consolidating the alphabetically organized codes by assigning frequencies to codes that looked similar. After that, sorting was done by placing codes into clusters in line with the three research questions, starting with the very first. After sorting codes, clusters were then labelled to form categories basing on ascending order of code frequencies (that's to say, those with higher frequencies appeared in the first cluster and so on) from which categories were finally united to form themes in the last stage.

Researchers expressed their views unmodified to ensure that voices were correctly identified and registered to understand how participants derived meaning from their experience or the effects and attitude towards Online Learning during the COVID 19 period. Data were organized around each research question, which related to the effects of online learning, student attitude towards online learning, and strategies used by the student to cope up with the challenges faced during their online learning classes. According to the themes obtained, the effects rounded to three themes: Poor network connectivity, Limited class participation, and finally, Reinforced learning. The student attitudes which reduced to two themes: Passion for online learning and Apathy for online learning. The last part, which dealt with the coping strategies, was also reduced to two themes: Prior classroom preparation and Seeking better internet connectivity.

To prevent contradictory information, the data was triangulated, while constant comparisons ensured adequate validation. Cross-checking of coded documents, interview notes, and original data analysis notes was conducted to achieve triangulation. Data triangulation from many participants who offered various online courses, to improve the conclusion of the study and to reduce the threats to validity, was carried out. Creswell (2008) described triangulation as the process of corroborating evidence from different individuals (e.g., a principal or students), forms of data (e.g., qualitative field observations and interviews), or data collection process (e.g., records and interviews) (p.266).

Corbin and Strauss (2008) suggested that the participant analysis be carried out to ensure that nothing was left out, which includes determining the accuracy of the data interpretation of the researcher from the participants. To ensure that the results represent both perspectives and viewpoints, we sent each participant transcripts and results. Their answers confirmed the recognition of their views, attitudes, and voices from the study.

Data analysis may generate contradictory views, outliers, or views which do not fit other data. We checked all data intending to solve the perceived differences to mitigate this possibility (Lodico et al., 2010). Glesne (2011) described several strategies for ensuring validity and confidentiality, including long-term engagement and continuous supervision, peer review and debriefing, analysis of negative events, transparency of researcher bias, participant evaluation, thick definition, and external audits. Interview transcripts for this study were validated using member checks and triangulation of data.

A qualitative data tool (NVivo 9) was considered but not used for the recovery, search, categorization, and code of text data (Lewins \& Silver, 2007) because themes had already been established through the description focused coding-based procedure. This common tool is often used to allow researchers to build codes and find themes in text data. According to three research questions, the data was uploaded. A theme collects vital information on the research question and represents some patterned answers or significance in collecting data. Data review consisted of a close first reading of the transcripts of the interviews. We took notes and noted similarities and differences in responses during the reading. The effects of online learning from the student's viewpoint and their attitudes towards online learning were explored using a constructivist-interpretation approach. This approach uses qualitative data collection and empirical methods to establish data meaning trends, according to Mackenzie and Knipe (2006). 


\subsection{Coding system}

Research question 1: How has online learning during the COVID-19 period affected southwest university international students' studies for the spring semester of 2020?

Table 1: Clustering of responses

\begin{tabular}{|c|c|c|c|c|c|}
\hline Cluster 1 & Cluster 2 & Cluster 3 & Cluster 4 & Cluster 5 & Cluster 6 \\
\hline $\begin{array}{l}\text { Lack of } \\
\text { Enthusiasm and } \\
\text { Active } \\
\text { Participation (2) } \\
\text { Attentive While } \\
\text { in Face to Face } \\
\text { Classes (1). } \\
\text { Difficulties in } \\
\text { Expressing } \\
\text { Questions (1). } \\
\text { Interaction Is Not } \\
\text { Good Between } \\
\text { Teacher and } \\
\text { Student (1) } \\
\text { Lack of Active } \\
\text { Participation (1) } \\
\text { Lazy at Typing } \\
\text { and Sending } \\
\text { Messages (1) } \\
\text { Limits Student } \\
\text { Interaction (2) } \\
\text { Learning } \\
\text { Efficiency Is } \\
\text { Reduced (1) } \\
\text { Poor Class } \\
\text { Attendance (1) } \\
\text { Poor } \\
\text { Communication } \\
\text { (1) Ptudent- } \\
\text { Poor Th } \\
\text { Teacher } \\
\text { Interaction (1). } \\
\text { Questions } \\
\text { Clear to Thet } \\
\text { Teacher (1). } \\
\text { Teacher Not Able } \\
\text { to Express Some } \\
\text { Calculations (1) } \\
\text { Difficulties } \\
\text { Expressing } \\
\text { Questions (1). }\end{array}$ & $\begin{array}{l}\text { Distraction } \\
\text { While Learning } \\
\text { (3). } \\
\text { Being Not Clear } \\
\text { with What's } \\
\text { Being Taught } \\
\text { (2) } \\
\text { Class } \\
\text { Distraction (1). } \\
\text { Experiments Put } \\
\text { on Hold (1) } \\
\text { Inconveniency } \\
\text { of } \\
\text { Classes (1) Online } \\
\text { Lack of } \\
\text { Practicability } \\
\text { (1) } \\
\text { Poor Learning } \\
\text { Environment (1) } \\
\text { Time of } \\
\text { Differences (1) } \\
\text { Ineffective } \\
\text { Learning Due to } \\
\text { Skipping of } \\
\text { Classes (1). } \\
\text { Stress and } \\
\text { Tension } \\
\text { Work (1). }\end{array}$ & $\begin{array}{l}\text { Poor Network } \\
\text { Connection } \\
\text { for Students } \\
\text { Abroad and } \\
\text { Outside } \\
\text { Campus (5) } \\
\text { Poor Network } \\
\text { Connectivity } \\
\text { (2) } \\
\text { Cut in The } \\
\text { Live Videos } \\
\text { (1). } \\
\text { Difficulties } \\
\text { Logging in } \\
\text { With Some } \\
\text { Apps (1) }\end{array}$ & $\begin{array}{l}\text { Effective } \\
\text { Communicatio } \\
\mathrm{n} \text { with the } \\
\text { Professor (3) } \\
\text { Better Class } \\
\text { Management } \\
(1) \\
\text { Improves } \\
\text { Class } \\
\text { Participation } \\
(1) \\
\text { Smooth } \\
\text { Connection } \\
\text { for Students } \\
\text { on Campus (1) } \\
\text { Convenience } \\
\text { While } \\
\text { Learning (1) }\end{array}$ & $\begin{array}{l}\text { Acted as } \begin{array}{l}\text { An } \\
\text { Option }\end{array} \text { for } \\
\text { Learning (5) } \\
\text { Gave Room to } \\
\text { Know More } \\
\text { About } \\
\text { Technology (1) }\end{array}$ & $\begin{array}{l}\text { Positively Due to } \\
\text { Its Ease While } \\
\text { Learning (3) } \\
\text { Positively, It } \\
\text { Improved } \\
\text { Students } \\
\text { Researching } \\
\text { Ability (1) } \\
\text { Positively, It } \\
\text { Improved } \\
\text { Students Studying } \\
\text { Ability and Pace } \\
\text { at Which Task } \\
\text { Are Done (1) }\end{array}$ \\
\hline
\end{tabular}


Table 2: Labelling of clusters

\begin{tabular}{|c|c|c|c|c|c|}
\hline $\begin{array}{l}\text { Cluster 1: lack } \\
\text { of active class } \\
\text { participation } \\
\text { and } \\
\text { collaboration } \\
\text { (16) }\end{array}$ & $\begin{array}{l}\text { Cluster 2: } \\
\text { Ineffective } \\
\text { learning } \\
\text { environment } \\
\text { (13) }\end{array}$ & $\begin{array}{l}\text { Cluster 3: } \\
\text { Poor internet } \\
\text { connectivity } \\
\text { (9) }\end{array}$ & $\begin{array}{l}\text { Cluster } \\
\text { Effective } \\
\text { communication } \\
\text { (7) }\end{array}$ & $\begin{array}{l}\text { Cluster 5: } \\
\text { Supported } \\
\text { continuous } \\
\text { learning. } \\
\text { (6) }\end{array}$ & $\begin{array}{l}\text { Cluster 6: } \\
\text { Ease while } \\
\text { learning and } \\
\text { improved } \\
\text { studying } \\
\text { ability } \\
\text { (5) }\end{array}$ \\
\hline $\begin{array}{l}\text { Lack of } \\
\text { Enthusiasm and } \\
\text { Active } \\
\text { Participation } \\
\text { (2) } \\
\text { Attentive While } \\
\text { in Face to Face } \\
\text { Classes (1). } \\
\text { Difficulties in } \\
\text { Expressing } \\
\text { Questions (1). } \\
\text { Interaction Is } \\
\text { Not Good } \\
\text { Between } \\
\text { Teacher and } \\
\text { Student (1) } \\
\text { Lack of Active } \\
\text { Participation } \\
\text { (1) } \\
\text { Lazy at Typing } \\
\text { and Sending } \\
\text { Messages (1) } \\
\text { Limits Student } \\
\text { Interaction (2) } \\
\text { Learning } \\
\text { Efficiency Is } \\
\text { Reduced (1) } \\
\text { Poor Class } \\
\text { Attendance (1) } \\
\text { Poor Tor } \\
\text { Communication } \\
\text { (1) } \\
\text { Poor Student- } \\
\text { Teacher } \\
\text { Interaction (1). } \\
\text { Questions Not } \\
\text { Clear to The } \\
\text { Teacher (1). } \\
\text { Teacher } \\
\text { Able to Express } \\
\text { Some } \\
\text { Calculations (1) } \\
\text { Difficulties in } \\
\text { Questions (1). }\end{array}$ & $\begin{array}{l}\text { Distraction } \\
\text { While Learning } \\
\text { (3). } \\
\text { Being Not } \\
\text { Clear with } \\
\text { What's Being } \\
\text { Taught (2) } \\
\text { Class } \\
\text { Distraction (1). } \\
\text { Experiments } \\
\text { Put on Hold (1) } \\
\text { Inconveniency } \\
\text { of Online } \\
\text { Classes (1) } \\
\text { Lack of } \\
\text { Practicability } \\
\text { (1) } \\
\text { Poor Learning } \\
\text { Environment } \\
\text { (1) } \\
\text { Time } \\
\text { Differences (1) } \\
\text { Ineffective } \\
\text { Learning Due } \\
\text { to Skipping of } \\
\text { Classes (1). } \\
\text { Stress and } \\
\text { Tension of } \\
\text { Work (1). }\end{array}$ & $\begin{array}{l}\text { Poor Network } \\
\text { Connection for } \\
\text { Students } \\
\text { Abroad and } \\
\text { Outside } \\
\text { Campus (5) } \\
\text { Poor Network } \\
\text { Connectivity } \\
\text { (2) } \\
\text { Cut in The Live } \\
\text { Videos (1). } \\
\text { Difficulties } \\
\text { Logging in } \\
\text { With Some } \\
\text { Apps (1) }\end{array}$ & $\begin{array}{l}\text { Effective } \\
\text { Communication } \\
\text { with The } \\
\text { Professor (3) } \\
\text { Better Class } \\
\text { Management } \\
\text { (1) } \\
\text { Improves Class } \\
\text { Participation (1) } \\
\text { Smooth } \\
\text { Connection for } \\
\text { Students on } \\
\text { Campus (1) } \\
\text { Convenience } \\
\text { While Learning } \\
\text { (1) }\end{array}$ & $\begin{array}{l}\text { Acted as An } \\
\text { Option for } \\
\text { Learning (5) } \\
\text { Gave Room to } \\
\text { Know More } \\
\text { About } \\
\text { Technology (1) }\end{array}$ & $\begin{array}{l}\text { Positively Due } \\
\text { to Its Ease } \\
\text { While Learning } \\
\text { (3) } \\
\text { Positively, It } \\
\text { Improved } \\
\text { Students } \\
\text { Researching } \\
\text { Ability (1) } \\
\text { Positively, It } \\
\text { Improved } \\
\text { Students } \\
\text { Studying } \\
\text { Ability and } \\
\text { Pace at Which } \\
\text { Task Are Done } \\
\text { (1) }\end{array}$ \\
\hline
\end{tabular}


Table 3: Formation of themes

\begin{tabular}{|l|l|l|}
\hline $\begin{array}{l}\text { Theme 1: Poor network } \\
\text { connectivity. (22) }\end{array}$ & $\begin{array}{l}\text { Theme 2: Limited class } \\
\text { participation (16) }\end{array}$ & $\begin{array}{l}\text { Theme 3: Reinforced learning. } \\
\text { (18) }\end{array}$ \\
\hline $\begin{array}{l}\text { Poor network connectivity (9) } \\
\text { Ineffective learning environment } \\
(13)\end{array}$ & $\begin{array}{l}\text { Lack of active class participation } \\
\text { and collaboration (16) }\end{array}$ & $\begin{array}{l}\text { continuous learning (6) } \\
\text { Effective communication (7) }\end{array}$ \\
& $\begin{array}{l}\text { Ease while learning and improved } \\
\text { studying ability (5) }\end{array}$ \\
\hline
\end{tabular}

Research question 2: What are the attitudes of SWU international students towards online learning during the COVID-19 period?

Table 4: Clustering of response

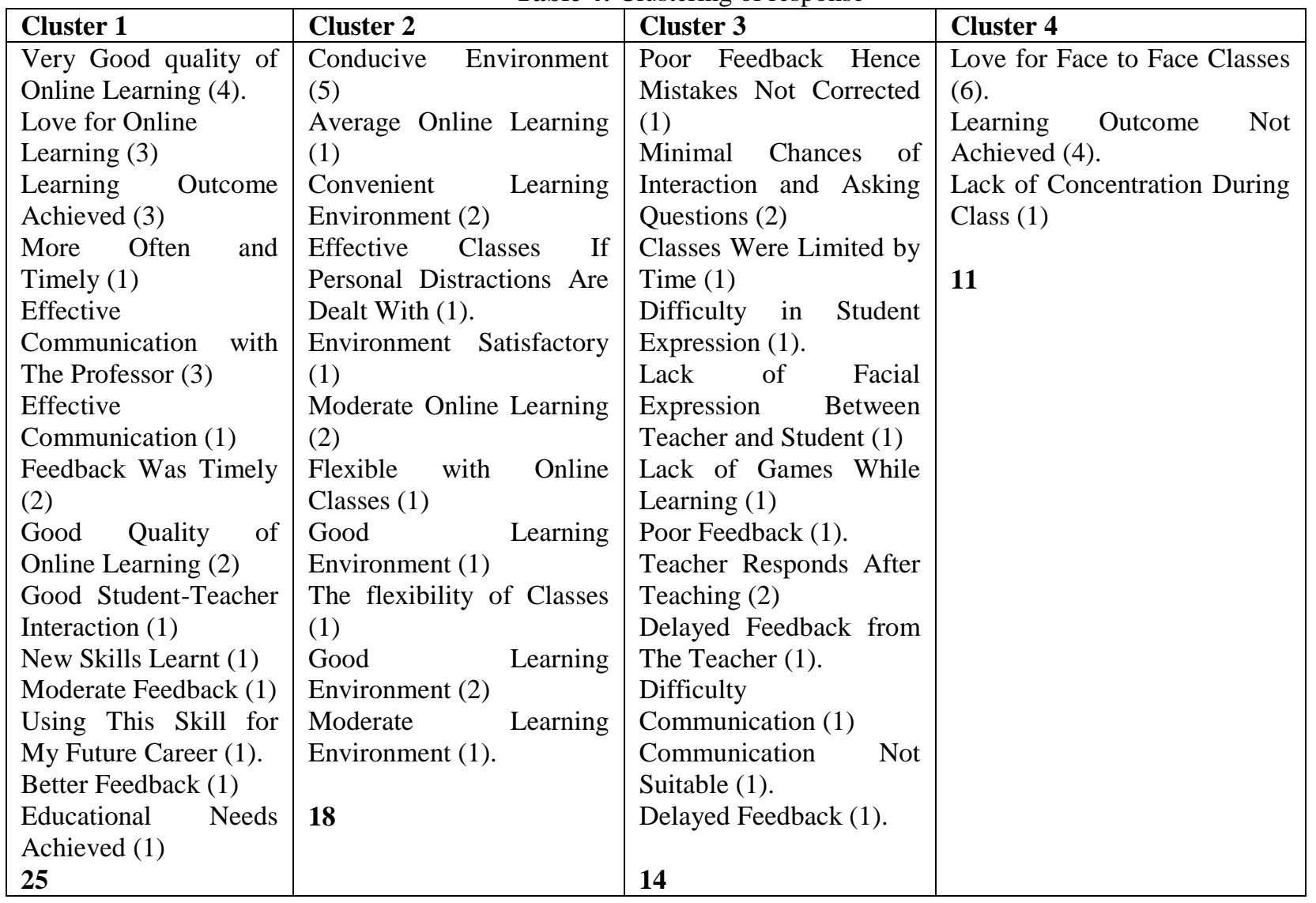


Table 5: Labelling of clusters

\begin{tabular}{|c|c|c|c|}
\hline $\begin{array}{l}\text { Cluster 1: } \\
\text { Passion for online } \\
\text { learning (25) }\end{array}$ & $\begin{array}{l}\text { Cluster 2: } \\
\text { Satisfying and flexible } \\
\text { online classes (18) }\end{array}$ & $\begin{array}{l}\text { Cluster 3: } \\
\text { A feeling of limited } \\
\text { personal expression and } \\
\text { interaction (14) }\end{array}$ & $\begin{array}{l}\text { Cluster4: } \\
\text { Apathy for online classes (11) }\end{array}$ \\
\hline $\begin{array}{l}\text { Very Good quality of } \\
\text { Online Learning (4). } \\
\text { Love for Online } \\
\text { Learning (3) } \\
\text { Learning } \\
\text { Achieved (3) Outcome } \\
\text { More Often and Timely } \\
\text { (1) } \\
\text { Effective Communication } \\
\text { with The Professor (3) } \\
\text { Effective Communication } \\
\text { (1) } \\
\text { Feedback Was Timely (2) } \\
\text { Good Quality of Online } \\
\text { Learning (2) } \\
\text { Good Student-Teacher } \\
\text { Interaction (1) } \\
\text { New Skills Learnt (1) } \\
\text { Moderate Feedback (1) } \\
\text { Using This Skill for My } \\
\text { Future Career (1). } \\
\text { Better Feedback (1) } \\
\text { Educational Needs } \\
\text { Achieved (1) }\end{array}$ & $\begin{array}{l}\text { Conducive Environment } \\
\text { (5) } \\
\text { Average Online Learning } \\
\text { (1) } \\
\text { Convenient Learning } \\
\text { Environment (2) } \\
\text { Effective Classes If } \\
\text { Personal Distractions Are } \\
\text { Dealt With (1). } \\
\text { Environment Satisfactory } \\
\text { (1) Online } \\
\text { Moderate } \\
\text { Learning (2) Online } \\
\text { Flexible with } \\
\text { Classes (1) } \\
\text { Good Learning } \\
\text { Environment (1) } \\
\text { Flexibility of Classes (1) } \\
\text { Good Learning } \\
\text { Environment (2) } \\
\text { Moderate Learning } \\
\text { Environment (1). }\end{array}$ & $\begin{array}{l}\text { Poor Feedback Hence } \\
\text { Mistakes Not Corrected } \\
(1) \\
\text { Minimal Chances of } \\
\text { Interaction and Asking } \\
\text { Questions (2) } \\
\text { Classes Were Limited by } \\
\text { Time (1) } \\
\text { Difficulty in Student } \\
\text { Expression (1). } \\
\text { Lack of Facial Expression } \\
\text { Between Teacher and } \\
\text { Student (1) } \\
\text { Lack of Games While } \\
\text { Learning (1) } \\
\text { Poor Feedback (1). } \\
\text { Teacher Responds After } \\
\text { Teaching (2) } \\
\text { Delayed Feedback from } \\
\text { The Teacher (1). } \\
\text { Difficulty } \\
\text { Communication (1) } \\
\text { Communication } \\
\text { Suitable (1). } \\
\text { Delayed Feedback (1). }\end{array}$ & $\begin{array}{l}\text { Love for Face to Face Classes } \\
\text { (6). } \\
\text { Learning Outcome Not } \\
\text { Achieved (4). } \\
\text { Lack of Concentration During } \\
\text { Class (1) }\end{array}$ \\
\hline
\end{tabular}

Table 6: Formation of Themes

\begin{tabular}{|l|l|}
\hline Theme 1: Passion for online learning. (43) & Theme 2: Apathy of online learning (25) \\
\hline Passion for online learning (25) & $\begin{array}{l}\text { A feeling of limited personal expression and interaction } \\
\text { Satisfying and flexible online classes (18) }\end{array}$ \\
& Apathy for online classes (11)
\end{tabular}

Research Question 3: How have international students of SWU managed to cope up with the challenges faced during online learning throughout the COVID-19 period?

Table 7: Clustering of responses

\begin{tabular}{|l|l|l|}
\hline Cluster 1 & Cluster 2 & Cluster 3 \\
\hline Personal Research After Class (2) & Looks for Places with WIFI (1) & Fully Charging Gadgets (1) \\
Quiet Place and After Class & Seek for Help from The Office (1) & Having Gadgets Ready Ahead of \\
Practicing (1) & Switch to Other Device to Attend & Time (1) \\
Consulting the Peers (1) & Class (1) & Using English Version Software \\
Asking Questions in The Group (1) & Having Enough Data (1) I Can Translate (1). \\
$\begin{array}{l}\text { Completing Assignments Intime (1) } \\
\text { Maximum Attention While in Class } \\
\text { (1) }\end{array}$ & $\begin{array}{l}\text { Interchanging of Network Wi-Fi To } \\
\text { Peading Before the Class (1). }\end{array}$ & $\begin{array}{l}\text { Using the International Version of } \\
\text { QQ (1). }\end{array}$ \\
$\begin{array}{l}\text { Creating A Routine of Working (1) } \\
{[8]}\end{array}$ & [5] & {$[4]$} \\
\end{tabular}


Table 8: Labelling of clusters

\begin{tabular}{|c|c|c|}
\hline $\begin{array}{l}\text { Cluster1: Personal research and } \\
\text { peer consultation. (9) }\end{array}$ & $\begin{array}{l}\text { Cluster2: Seeking better network } \\
\text { connection (5) }\end{array}$ & $\begin{array}{l}\text { Cluster3: Good class preparation } \\
\text { (4) }\end{array}$ \\
\hline $\begin{array}{l}\text { Personal Research After Class (2) } \\
\text { Quiet Place and After Class } \\
\text { Practising (1) } \\
\text { Consulting the Peers (1) } \\
\text { Asking Questions in The Group (1) } \\
\text { Completing Assignments Intime } \\
\text { (1) } \\
\text { Maximum Attention While in Class } \\
\text { (1) } \\
\text { Reading Prior to the Class (1). } \\
\text { Creating A Routine of Working (1) }\end{array}$ & $\begin{array}{l}\text { Looks for Places with WIFI (1) } \\
\text { Seek for Help from The Office (1) } \\
\text { Switch to Other Device to Attend Class } \\
\text { (1) } \\
\text { Having Enough Data (1) } \\
\text { Interchanging of Network Wi-Fi To } \\
\text { Phone Mobile (1) }\end{array}$ & $\begin{array}{l}\text { Fully Charging Gadgets (1) } \\
\text { Having Gadgets Ready Ahead of } \\
\text { Time (1) } \\
\text { Using English version software } \\
\text { where I can translate (1). } \\
\text { Using the International Version of } \\
\text { QQ (1). }\end{array}$ \\
\hline
\end{tabular}

Table 9: Formation Themes

\begin{tabular}{|l|l|}
\hline Theme 1: Prior class preparation (13) & Theme 2: Seeking better connectivity (5) \\
\hline $\begin{array}{l}\text { Personal research and peer consultation (9) } \\
\text { Good class preparation (4) }\end{array}$ & Seeking better network connection (5) \\
\hline
\end{tabular}

\subsection{Results and Findings}

Findings: This study's purpose was to investigate the impacts of online learning during the COVID 19 period and students' attitudes towards online. The effects of online learning on students and their attitudes were examined.

The report's findings will be grouped into three sections: Effects, Student attitude, and Coping up strategies. With the effects, this part's initial coding resulted in six categories that were further merged to form the three themes (Poor network connectivity, Limited class participation, and finally, Reinforced learning). Initially, the student attitudes section consisted of four categories which were merged to form two themes (Passion for online learning and Apathy for online learning) and final, the coping up strategies section initially consisted of three categories that reduced to two themes after unitizing them (Prior classroom preparation and Seeking better internet connectivity).

Effects of online learning: The effects can be further sub-divided into two i.e., the negative and positive effects.

\subsection{Negative effects}

\subsubsection{Poor network connectivity:}

Most of the students aired out having challenges with internet connectivity during their online classes. This theme emerged as the strongest because both students abroad and those within China had connectivity issues. Respondent outside China: "Connection problem sometimes, if your connection problem sometimes if not good you do not keep up with what the teacher is saying, connection and internet speed". Respondent in china: "uhm, for the online session that we had uhm, there were few challenges, but the greatest of all was sometimes uhm, we here, we in china here, uhm there is a cut in the live vid, even though the network is good sometimes there is a cut in the live video, you are not able to respond to the teacher and the teacher is also not able to respond to you". Respondent: "I have series of challenges especially on the parts of my network most time I've to struggle with network, and then sometimes, uhm the time... the timing like I had a course the teacher was always just giving works for us to submit" Respondent: "Network, was a problem mostly, sometimes Wi-Fi or mobile network it is good sometimes is low". At the same time, teacher-student interaction was negatively affected still due to poor internet connections. Respondent: "It was boring because I just listening, listening it's hard to have interactive thought because of network or because the teacher cannot use the application so expert." Respondent: "uhm...I encountered few challenges, we had a challenge of network, internet sometimes when the network is weak you cannot be able to attend the class, or the class presentation is cutting. Sometimes we cannot hear each other" Respondent within campus: "I think the most challenges is the internet problem". This was evident enough to prove that poor internet connectivity negatively affected students during their online learning sessions. Students, therefore, need a well and smooth connectivity if their online classes are to be both efficient and effective. 


\subsubsection{Limited Cass Participation}

Limited Class participation emerged as the second strongest theme after several students fronting it as one of the major effects they had during their online learning. Respondent within campus: "The engagement is not as much as when you are in class. And even for me, the enthusiasm to contribute is not so much, I just receive (like a recipient) there's no active participation. I just listen and listen and even when I have a question, I just maybe try figuring out the answer myself. So, I think it's a challenge, active participation is not as though one was in class." In any environment, for learning to be effective, communication and participation must go hand in hand. One of the participants mentioned that evading classes would as well be an easy thing since the teacher would never be able to know whether the student is attending or only logged in. Respondent: "As a matter of fact, it's easy to evade the classes themselves so the quality of knowledge attained may not be as accurate as that attained in the face to face classes where people sit down and attend physically. So, the challenge is it gives people room to omit some of the classes for as long as you are signed in, the teacher may not clearly tell whether you are actually in class or the gadget is in class." Student opinions come from the real-life experience of online learning since all attended classes online. This kind of learning was majorly teachercentered hence lowering down the participation rate for students, something that could not enhance students' livelihood while learning.

\subsection{Positive effect}

\subsubsection{Reinforced Learning:}

Some of the students stressed the fact that even with the presence of the Covid-19, study/learning never ceased because online classes acted as an option for continuous learning. Respondent: "oh yes yeah umm, I would say positive manner because in times of crisis you have to adjust, and this Covid-19 came out of nowhere and the school had to impromptu initiate this policy and has helped us a lot". Another student pointed out that something is better than nothing hence siding with online learning. Respondent: "Well something better than nothing. So, I was taken that positively at the start, but you can't compare with face to face." Respondent: "so yeah! It has, I have learned sometimes from online learning although it was tough one, so we must concentrate but we learned. I had to find ways to cope with a new method of teaching and I learned, and I have passed very well." Respondent: "And the advantages on the other hand it saved us of the situation where we would go without classes because it was an option. Secondly, I entirely applaud technology". Online learning, therefore, gave room for continuous studies even when Covid-19 tried acting as a barrier. Furthermore, one of the respondents said that he learnt a lot in line with technology since online learning was the only option for him to have classes. Respondent: "And the other advantage is it gave room to know how to use technology which is something that I've never done before so it was an opportunity and soon, those skills attained can be invested or employed during the carriers in future when employed". It was a lot that students benefited from online learning since too many, it was their first encounter with this type of instruction/learning.

\subsection{Student attitude towards online learning:}

Initial coding of this anchor code resulted into four categories (Passion for online learning, satisfying and flexible online classes, A feeling of limited personal expression and finally Apathy for online classes) that were further merged to form two themes ( Passion of online leaning and Apathy for online learning).

\subsubsection{Passion for online learning:}

The convenience of online education and conduciveness of the class environment has been widely recognized as one of the contributing factors to the students' passion for online learning during the Covid-19 period. The most important factor that contributed to participants' passion for online learning was the conduciveness of the class environment during participation time and the convenience nature of classes. All the twelve participants in this study emphasized the convenience they enjoyed from not being required walking to classes early in the morning, plan their work and study at their own time. Conduciveness of the classes' environment from the comfort of their homes/hostels was one positive experience found in this study. Students could log into the online course at any place where they are available usually from their homes/hostels. "because it was home it was comfortable it was ok." "Yeah I was in my room, so the environment was good" "The environment was friendly" "Better environment Good..." The participants felt convenience was also important because they could attend classes do other domestic chores "the online learning is very convenient in for the fact that you can be in class while you are in bed, and you can be in class while you are busy cooking and so it is quite flexible..." "It was convenient, no noise, no distraction." "Yeah I like the online learning in terms of the convenience" Participants also perceived online learning as an enjoyable experience when studying with no pressure from the teacher and the other students. "the thing I liked about it is that I download the materials, I divide them 
into my week and I do them according to my plan I don't have to take any else's plan and arrange it to myself I can arrange myself..."

Some of the students agreed to their learning outcomes being achieved through the online learning hence developed passion. "my learning outcome was achieved because it was all about research and professors were sharing the PPT and some of the images still stand up for me." "it made me like got this interest and then I had to research more so it even made me knew more about the course." However, some students felt that they only acquired new skills which they can use in future. "I use this kind of method in the future study" "I just learn a new skill which is called online presentation." Some students acknowledged that feedback was on time and that learning was interactive. "you just ask a question and it was very timely." "Even if you ask the question you can ask through, We-Chat and then they would reply to you"

\subsubsection{The apathy of online learning}

Lack of interactivity was the major factor that made most students develop Apathy for online classes as "it was limited by time and teacher would stick to the stipulated time," "Not enough communication." Other participants had apathy because they felt it was not suitable "classes not good overall experience is not suitable for me." To others it was a matter of preference "online communication in a problem is not the best choice so for that would prefer face to face", "I prefer the face to face class because they give you the feel of what's happening." while others had apathy due to lack of interactivity "minimal chances for interactions and asking questions so that's a challenge as you are to compare it with the face to face classes." Some students looked at lack of facial expression as draw back. "Compared to the face to face you know the face to face the teacher is like able to base on your facial expression to know if you understand or not"

Finally, poor feedback from the teachers was conceived as the other factor which shaped students' negative experience on the quality of online learning. Students expected to receive timely feedback from teachers on assignments submitted. But this was not case with some teachers "comment maybe after a day or two maybe when your mind is off that topic or what it is, you're about to learn the teacher might respond".

\subsection{Coping Strategies}

It was not easy for SWU students to instantly adapt to unplanned online learning classes after traditional classroom learning at covid-19 in spring semester 2020. Because of this change, some of them encountered difficulty in learning. However, the most important decisions they could ever make was to accept the newly implemented learning approach (online learning) with an open mind and therefore seek immediate solutions and coping strategies to problems encountered. During the discussion, three categories (Personal research and peer consultation, seeking better network connection and Timely class preparation) related to the coping strategies were obtained and further merged into two themes (Prior class preparation and Seeking better connectivity).

\subsubsection{Prior class preparation}

Participants indicated that they needed to followed other techniques, such as peer review and consultation, by asking other peers questions where they did not understand professor during the course. Some of the participants also specified that they created WeChat group platforms for students only so they could quickly communicate and discuss their schoolwork effectively before the lesson started as an attempt to keep up with online learning. Other respondents voiced that they had to visit various data sources and search engines for more information and further understanding. "...you have to search online, visit google, Baidu just to get the data or information that you want so that is a coping strategy that most of us used and we also have a WeChat group for students that we have interactions and ask about some aspects of what has been taught that we did not understand."

Furthermore, some participants also added that for the smooth online class session they had to buy enough data bundles and double-check their electronic devices if they are in good condition to carry on with class. While other participants articulated that they had good communication with the instructor and thus directly consulted for further explanations where they did not understand during learning sessions. "... I have good communication with the teacher in class and outside the class." While the other participant, "I had network issues, which I resolved. Instead of using my phone, because my phone had poor network connectivity so I had to switch to using a computer, so I had to make sure that I have enough Wi-Fi credits so that I attend class without any disruptions."

\subsubsection{Seeking better network connection}

The study shows that many students were not well equipped with a high-speed internet connection during online learning which is usually required for online learning. Because of this problem, they faced problems with online learning going live and other sessions that needed to connect online. A slow internet connection seemed to be a major issue for most students in China and abroad. However, there are solutions that they have implemented, such as seeking for places with better internet $\mathrm{Wi}-\mathrm{Fi}$, one respondent uttered that, "for some students who went back to their countries there is no Wi-Fi, so they have to go to some places with Wi-Fi." Buying data credits on time and switching to other devices also 
emerged as coping strategies, "I had network issues, which I resolved. Instead of using my phone, because my phone had poor network connectivity so I had to switch to using a computer so I had to make sure that I have enough Wi-Fi credits so that I attend class without any disruptions."

\subsection{Discussion and Conclusion}

The study's purpose was to explore the impacts of online learning and an understanding of the students' attitudes towards online learning during the COVID 19 period of the spring semester 2020. The qualitative research method used in the study was suitable to achieve this goal. The depth of information gained through the analysis of interviews provided a level of understanding the quantitative methods could not.

The findings showed that poor network connectivity emerged as the strongest theme that students found challenging during their online learning sessions, of which some ended up missing lessons. This finding confirms the assertion by Wang (2020), which showed that because of the poor internet access, students do not completely use the online lessons. The findings further confirmed that poor class interaction too greatly affected students during their online learning period. This finding is in line with (Yang \& Lin, 2010), who stated that learning, discussions exchange of information usually found in face-to-face learning is viewed differently in online learning.

For as far as students' attitude towards online learning is concerned, the study affirms that students had a passion for online classes amidst most of the challenges faced. Applauding technology and acknowledging that online learning acted as an option for learning were some of the responses strongly aired out by participants. These findings affirm Sun et al. (2008), who cited Piccoli et al. (2001) finding that students would become more comfortable and successful in online learning if they are not afraid of uncertainty in information technology (positive attitude). We, therefore, think that online learning played a crucial role, something we never expected at the beginning of our study.

On the other hand, not all attitudes were positive because some of the participants' responses confirmed that online learning wasn't the best for them. It was realized that there was a feeling of limited personal expression and low interactions during online classes, which later resulted in poor feedback from the instructors. Petride's (2002) study on learners' perspectives on web-based learning also reported that some of the participants felt a lack of response in the online context concerning what could occur during the physical face to face interaction.

This study has some limitations. It only focused on one university (southwest university Chongqing). It can, therefore, not be generalized on a large scale of universities in China. Furthermore, the sampling method used was the convenient sampling of which, if a different approach is used, results could as well be different.

In conclusion, results of this study have shown that due to the pandemic during the spring semester of 2020 and having online learning as the only option, students faced some challenges in the form of positive and negative effects, their attitudes were either positive or negative, but at the end of the day, they had strategies to solving the challenges faced.

Furthermore, the researchers found that the teachers' technological competencies play a key role while making sure that quality online learning takes place. This is not only because teachers are in direct contact with the students, but also, they are responsible for students achieving their learning outcomes. More importantly, the teachers should make use of all avenues of online teaching platforms, from PPTs accompanied by voice explanations, videos, recorded lessons to live to stream. This will help mitigate the network challenge, which emerged as the greatest effect on students' studies. This is so as the finding of this study shows that poor internet connectivity as a negative effect, included difficulties in connections during online learning regardless of the student's location since even students within china faced this challenge. This does not however mean that students should be set aside to ensure quality online learning. Instead, students should be disciplined as it will help them develop a positive attitude towards online learning. On the other hand, the administrator should provide enough support to teachers handling online classes inform of training, monetary, and promotional. They can also hire qualified online teachers to conduct workshops with the university teachers and motivate them to provide effective online teaching.

Low-class participation has also been displayed in this study. Due to the lack of face to face interaction, students could easily omit classes, and this came as a result of boredom during online learning. Teachers could not as well effectively monitor students actively logged in for learning since it was so easy for a student to just log in and mute his/her presence. This further led to poor feedback from the teachers hence affecting the overall online learning process. Teachers should, therefore, be well suited on how to monitor students during online classes because this will positively boost learning by them (teachers) achieving their set objectives and the students gaining from this type of learning.

It has also been discovered from this study that online learning enabled in the continuity of studies because it was the only option left. Had it not been it, learning would have ceased. Its, therefore, from this point that students applauded technology for its contribution to the academic sector. Most of the students learned new skills that will perhaps be of help to them in their future carriers and further studies for those that need to be in the academic field. Besides the challenges faced, it is recommended to join online learning for it accelerates the learning process. Therefore, the university should put in place what is required to have classes online just in case unavoidable situations like this came in. This further explains the positive attitude students had towards online learning. They were passionate and felt not left out during this pandemic. 
For the challenges faced during online learning, students used several strategies to cope up. Prior class preparation in terms of carrying out personal research and participating actively in class are so crucial if the learning process is to be effective. Seeking better internet connectivity, too, was paramount for several students who brought it up as one of the helpful strategies used to have better online classes. The university should, therefore, have better connections that enable students to smoothly have online classes.

\subsection{Strengths and Limitations}

A potential weakness of case studies is that a researcher can cause the course of the results and conclusions to be affected by unclear information or biased views (Yin, 2009, p. 14). In this research, by engaging in bracketing, a method of recognizing possible bias and then setting aside (bracketing) any preconceived concepts that could interfere with objective collection and analysis of data, we minimized that possibility. According to Tufford (2010), bracketing is a "method used to mitigate the potentially deleterious effects of preconceptions that may affect the research process in qualitative research" (p. 83). Reliability is the degree to which another researcher may reproduce a study using the same processes and achieve similar results (Yin, 2009). In this research, reliability was reinforced by reporting the interview protocol used, transmitting data in their own words by participants, and triangulating data (Creswell, 2009; Lodico et al., 2006; Merriam, 2009; Stake, 2011; Yin, 2009). Data collected from participants were analysed and linked to the four factors of Moore's Distance Theory were the corresponding themes that emerged (1993). Despite these provisions, there were drawbacks to the present analysis. One was the sample size: 12 student participants from various departments in online studies at a single university who had different courses. Study findings do not extend to other universities or divisions, nor may they be extended to a wider spectrum. The sample size of 12 student participants was selected because a larger sample size may warrant longer study time in the field, and before reducing the sample size to 12, the possibility of saturation was considered. Also, because no statistical test was planned, the sample size for this analysis was considered enough. We hired an independent reviewer to analyse and scrutinize the interview details to correct the shortcomings and ensure the validity of this report. Finally, the purpose of the study and the three research questions intended for this study were considered and we determined that a sample size of 12 would adequately provide appropriate data for analysis and interpretation.

\subsection{Recommendations for Further Study}

It is anticipated that online course programs will continue to expand and that the problems facing online learners will demand continuous attention (Allen \& Seaman, 2011; Brown \& Wrisley, 2009; Noel-Levitz, 2013). Participants in this study were asked on what they think should be done to improve the online learning experience of students in SWU. One of the participants pointed out the improvement of the relationship between teachers and students during online classes. This, therefore, brings in a gap for further research on how online communication of teachers and students should be improved. The university authorities should also research on students' satisfaction as the enrolment in online programs continues to grow and the fact that the pandemic is still in existence and showing no signs of stoppage mostly in countries outside China, international students are still expected to attend classes online.

\section{REFERENCES}

Adu, P. (2019). A step-by-step guide to qualitative data coding. Oxford: Routledge.

Allen, I. E., \& Seaman, J. (2011). Going the distance: Online education in the United States, 2011. Retrieved from http://www.onlinelearningsurvey.com/reports/ goingthedistance.pdf

Artino, A. R. \& Stephens, J. M (2009). Academic Motivation and Self-Regulation: A Comparative Analysis of Undergraduate and Graduate Students Learning Online. Internet and Higher Education, 12.

Baron, T. (2000). Getting IT Support for E-Learning. Training and Development, 54(12), 32-37.

Bai, Y., Lin, C. C., Chen, J. Y., Chue., C. M., \& Chou, P. (2004). Survey of stress reactions among health care workers involved with the SARS outbreak. Psychiatry. Serv. 55, 1055-1057. doi: 10.1176/appi.ps.55.9.1055.

Bao, W. (2020). COVID -19 and online teaching in higher education: A case study of Peking University. Human Behavior and Emerging Technologies, 2(2), 113-115. https://doi.org/10.1002/hbe2.191.

Bierema, L. \& Hill, J. (2005). "Virtual mentoring and HRD". Advances in Developing Human Resources.7(4), 556-568. 
Bierema, L. L., \& Merriam, S. (2002). E-mentoring: Using computer-mediated communication to enhance the mentoring process. Innovative Higher Education. 26, 211-227.

Bradford, G., \& Wyatt, S. (2010). Online learning and student satisfaction: Academic standing, ethnicity, and their influence on facilitated learning, engagement, and information fluency. Internet and Higher Education, 13.

Brazendale, K., Beets, M. W., Weaver, R. G., Pate, R. R., Turner-McGrievy, G. M., Kaczynski, A., et al. (2017). Understanding differences between summer vs. school obesogenic behaviors of children: the structured day's hypothesis. Int. J. Behav. Nutr. Phys. Act 14:100. doi: 10.1186/s12966-017-0555-2.

Brooks, S. K., Webster, R. K., Smith, L. E., Woodland, L., Wessely, S., Greenberg, N., et al. (2019). The psychological impact of the quarantine and how to reduce it: a rapid review of the evidence. Lancet 395, 912-920. doi: 10.1016/S01406736(20)30460-8

Brown, S. T., \& Wrisley, C. D. (2009). Evaluative parameters of an online nursing program from learners' perspectives. Journal of Nursing Education, 102(2), 209-226.

Burgess, S., \&Sieversten, H. H. (2020). School skills and learning: The impact of COVID 19 on education. Retrieved from https://voxeu.org/article/impact-covid-19-education.

Cantoni, V., Cellario, M., \& Porta, M. (2004). Perspectives and Challenges in E-learning: Towards Natural Interaction Paradigms. Journal of Visual Languages and Computing, 15, 333-345.

Chang, M. (2005). Applying self-regulated learning strategies in a web-based instruction - An investigation of motivation perception. Computer Assisted Language Learning, 18(3).

Cheng, R. (2020). The COVID-19 crisis and international students. https://www.insidehighered.com/views/2020/03/19/higher-ed-institutions-arent supporting-international-studentsenough-during-COVID Times Higher Education. 2020.

Corbin, J., \& Strauss, A. (2008). Basics of qualitative research: Techniques and procedures for developing grounded theory (3rd ed.). Thousand Oaks, CA: Sage.

Creswell, J. W. (2009). Research design: Qualitative, quantitative, and mixed method approaches (3rd ed.). Thousand Oaks, CA: Sage.

Donitsa-Schmidt, S., \& Topaz, B. (2018). Massive open online courses as a knowledge base for teachers. Journal of Education for Teaching, 44(5), 608-620. https://doi.org/10.1080/02607476.2018.1516350.

Douglas, D. E \& Van Der Vyver, G. (2004). Effectiveness of E-Learning Course Materials for Learning Database Management Systems: An Experimental Investigation. Journal of Computer Information Systems, 44(4), 41-48.

Demuyakor, J., 2020. Online journal of communication and media technologies. coronavirus-covid-19-and-onlinelearning-in-higher-institutions-of-education-a-survey-of-the-perceptions-of-ghanaian-international-students-in-china, 1(1), pp. 24-26.

Dong, J., 2020. Online Learning and Teaching Experiences During the COVID-19 Pandemic. English Linguistics Research, 9(2), p. 37.

Filius, R. M., Kleijn, R. A. M., Uijl, S. G., Prins, F. J., Rijen, H. V. M., \& Grobbee, D. E. (2019). Audio peer feedback to promote deep learning in online education. Journal of Computer Assisted Learning, 35(5), 607-619. https://doi.org/10.1111/jcal.12363.

Gordon, J. (2003). E-learning Tagged as Best Corporate IT Investment. E-learning, 4(1),8.

Govindasamy, T. (2002). Successful Implementation of e-learning pedagogical considerations. The Internet and Higher Education, 4, 287-299.

Glesne, C. (2011). Becoming qualitative researchers: An introduction (4th ed.). Boston,MA: Pearson Education, Inc. Glesne, C. (1999). Becoming qualitative researchers (2nd ed.). New York: Addison Wesley Longman. 
Hannafin, J. J. \& Cole, D. D. (1983). An analysis of why students select introductory high school computer coursework. Educational Technology, 23(4), 26-29.

Ho, L. A. \&Kuo, T. H. (2010). How can one amplify the effect of e-learning? An examination of high-tech "employees' computer attitude and flow experience. Computers in Human Behavior, 26.

Ismail, J. (2002). The Design of an E-learning system beyond the Hype. Internet and Higher Education, 4(3-4), 329-336. Keengwe, J. \& Kidd, T. T. (2010). Towards Best Practices in Online Learning and Teaching in Higher Education. MERLOT Journal of Online Learning and Teaching, 6 (2).

Laaser, W. (2011). Economics of distance and online learning: Theory, practice and research. International Review of Research in Open and Distance Learning, 12(2), 138-148.

Lewins, A., \& Silver, C. (2007). Using software for qualitative data analysis: A step-by step guide. London, UK: Sage.

Liaw, S. S. Huang, H. M. \& Chen, G. D. (2007). "An activity-theoretical approach to investigate learners" factors toward e-learning systems, Computers in Human Behaviour, 23.

Liaw, S. S., Huang. H. M., \& Chen, G. D. (2007). Surveying Instructor and Learner Attitudes toward eLearning. Computer \& Education, 49,7 .

Liu, X., Kakade, M., \& Fuller, C. J. (2012). Depression after exposure to stressful events: lessons learned from the severe acute respiratory syndrome epidemic. Compr. Psychiatry 53, 15-23. doi: 10.1016/j.comppsych.2011.02.003.

Lodico, M., Spaulding, D. T., \&Voegtle, K. H. (2010). Methods in educational research: From theory to practice. San Francisco, CA: John Wiley \& Sons.

Lynn Fish, C. R. S., 2014. A Preliminary Study of International Student Perceptions of Online versus Face-to-Face Education Web Appendix. The BRC Academy Journal of Business, 5(1), pp. 45-49.

Muhammad Adnan, K. A., 2020. Online learning amid the COVID-19 pandemic: Students' perspectives. Journal of Pedagogical Sociology and Psychology, 2(1), pp. 42-67.

Mackenzie, N., \& Knipe, S. (2006). Research dilemmas: Paradigms, methods and methodology. Issues in Educational Research, 16(2), 193-205.

Merriam, S. B. (2009). Qualitative research: A guide to design and implementation. San Francisco, CA: Jossey-Bass.

Mertens, D. M. (2005). Research methods in education and psychology: Integrating diversity with quantitative and qualitative approaches (2nd ed.) Thousand Oaks, CA: Sage.

Murphy, M. P. A. (2020). COVID-19 and emergency eLearning: Consequences of the securitization of higher education for post-pandemic pedagogy. Contemporary Security Policy, 1-14. https://doi.org/10.1080/13523260.2020.1761749.

Novikov, P., 2020. Research Impact of COVID-19 Emergency Transition to On-line learning on International Students' Perceptions of Educational Process at Russian University. Journal of Social Studies Education Research, 11(3), pp. 270302 .

Noel-Levitz (2013). 2013 national adult learners' satisfaction-priorities report. Retrieved from www.noellevitz.com/Benchmark

Oreopoulos, P, T von Wachter, \& A Heisz (2012), "The Short- and Long-Term Career Effects of Graduating in a Recession", American Economic Journal: Applied Economics 4(1): 1-29.

Pandey, P., \& Pandey, M. M. (ed.). (2015). Research Methodology: Tools and techniques (5th ed.). Romania, European union. Bridge center.

Peng, H., Tsai, C.-C, \& Wu, Y. T. (2006). University students" self-efficacy and their attitudes toward the Internet: the role of students' perceptions of the Internet. Educational Studies, 32, 7386. 
Petrides, L. A., (2002). Web based technologies for distributed (or distance) learning: Creating learner centred education experiences in the higher education classroom. International journal of instructional media, 29(1), 69-77.

Piccoli, G., Ahmad, R., \& Ives, B. (2001). Web-based virtual learning environments: a research framework and a preliminary assessment of effectiveness in basic IT skill training. MIS Quarterly, 25(4), 401-426.

Pituch, K.A. \& Lee, Y-K. (2006). The influence of system characteristics on e-learning use. Computers \& Education, 47.

Richardson. J. C., \& Swan, K. (2003). Examining social presence in online courses in relation to students' persceived learning and satisfaction. Journal of Asynchronous Learning Network, 7(1)

Rith-Najarian, L. R., Boustani, M. M., \& Chorpita, B. F. (2019). A systematic review of prevention programs targeting depression, anxiety, and stress in university students. J. Affect. Disord. 257, 568-584. doi: 10.1016/j.jad.2019.06.035.

Rosenberg, M. J. (2001). E-learning Strategies for Delivering Knowledge in the Digital Age. New York: McGraw-Hill. Sandars, J., \& Langlois, M. (2005). E-learning and the Educator in Primary Care: Responding to the Challenge. Education for Primary Care, 16, 129-133.

Selim, H. M. (2007). Critical success factors for e-learning acceptance: Confirmatory factor models. Computers \& Education. 49.

Shang, J., \& Cao, P. (2017). "Internet plus" and the reform of higher education: A preliminary study on the development strategy of higher education informatization in China. Peking University Education Review, 1, 173- 182.

Sprang, G., \&Silman, M. (2013). Posttraumatic stress disorder in parents and youth after health-related disasters. Disaster. Med. Public Health Prep. 7, 105-110. doi: 10.1017/dmp.2013.22.

Soni, V. D., 2020. Global Impact of E-learning during COVID 19. SSRN Electronic Journal, 1(1), pp. 12-18.

Stake, R.E. (2010). Qualitative research: Studying how things work. New York, NY: Guilford Press.

Taylor, M. R., Agho, K. E., Stevens, G. J., \& Raphael, B. (2008). Factors influencing psychological distress during a disease epidemic: data from Australia's first outbreak of equine influenza. BMC Public Health 8:347. doi: 10.1186/14712458-8-347.

Tufford, L. (2010). Bracketing in qualitative research. Qualitative Social Network, 11(1), 80-96. UNESCO. (2020, Match 13). COVID-19 educational disruption and response. Retrieved from https://en.unesco.org/covid19/educationresponse.

Wu, P., Fang, Y., Guan, Z., Fan, B., Kong, J., Yao, Z., et al. (2009). The psychological impact of the SARS epidemic on hospital employees in China: exposure, risk perception, and altruistic acceptance of risk. Can. J. Psychiatry 54, 302-311. doi: 10.1177/070674370905400504.

Yang, Y., \& Lin, N.C. (2010). Internet perceptions, online participation and language learning in Moodle forums: A case study on nursing students in Taiwan. Procedia Social and Behavioral Sciences, 2.

Yin, R. K. (2009). Case Study Research: Design and Methods (4th ed.). Thousand Oaks, CA: Sage Publications.

Zhang, T., Gao, T., Ring, G., \& Zhang, W. (2007). Using online discussion forums to assist a traditional English class. International Journal of E-Learning, 6(4), 623-643.

Zuochen Zhang, R. F. K., (2010). Learning in an Online Distance Education Course: Experiences of Three International Students. International Review of Research in Open and Distance Learning, 12(1), pp. 34-38. 